\title{
Genetic evidence extends the known distribution of Octopus insularis to the mid-Atlantic islands Ascension and St Helena
}

\author{
MICHAEL D. AMOR ${ }^{1,2}$, VLADIMIR LAPTIKHOVSKY ${ }^{3}$, MARK D. NORMAN $^{2}$ AND JAN M. STRUGNELL ${ }^{1}$ \\ ${ }^{1}$ Department of Ecology, Environment and Evolution, La Trobe University, Kingsbury Dr, Melbourne, Victoria 3086, Australia, \\ ${ }^{2}$ Sciences, Museum Victoria, 11 Nicholson St, Carlton, Victoria 3053, Australia, ${ }^{3}$ Fisheries Division, Centre for Environment, \\ Fisheries and Aquaculture Science (CEFAS), Pakefield Road, Lowestoft NR33 oHT, UK
}

\begin{abstract}
Recent molecular studies have proved beneficial in providing taxonomic resolution within the Octopus vulgaris species complex, therefore aiding in the appropriate management of this high value global fisheries resource. This study used the mitochondrial 'barcode of life' gene Cytochrome Oxidase subunit I (COI) to investigate the identity of shallow-water benthic octopuses in the mid-Atlantic Ocean and their relationship to members of the Octopus vulgaris species complex. Maximum likelihood and Bayesian phylogenetic inference placed individuals collected from two tropical islands, Ascension and St Helena, into a highly supported monophyletic clade with the North Brazilian species $\mathrm{O}$. insularis $(B S=81, P P=1)$, extending the known distribution of $\mathrm{O}$. insularis to Ascension and St Helena Islands. Octopus vulgaris and two other member species of the $\mathrm{O}$. vulgaris species complex, $\mathrm{O}$. tetricus and $\mathrm{O}$. cf. tetricus formed a highly supported monophyletic clade $(B S=99, P P=1)$. Interspecific distances between the $\mathrm{O}$. mimus group $(\mathrm{O}$. mimus, $\mathrm{O}$. bimaculoides, $\mathrm{O}$. maya and $\mathrm{O}$. insularis) and the $\mathrm{O}$. vulgaris species group (O. vulgaris, $\mathrm{O}$. tetricus and $\mathrm{O}$. cf. tetricus) ranged from 14.7-26.0\%, and an estimated date of divergence suggests these groups diverged from a common ancestor between 19.0 and 40.9 million years ago.
\end{abstract}

Keywords: Octopus vulgaris, O. occidentalis, O. sanctaehelenae, COI, phylogenetics, taxonomy, cryptic species complex, marine invertebrate

Submitted 3 November 2014; accepted 29 May 2015; first published online 2 September 2015

\section{INTRDDUCTION}

The benthic octopuses (family Octopodidae) are commercially important fisheries species with an estimated value of \$US 1.3 billion per annum (FAO, 2012). However, the historically poor taxonomy of this group remains an impediment to appropriate management of this fisheries resource, with only four of the estimated $100+$ targeted species listed in official catch statistics (Octopus vulgaris, O. maya, Eledone cirrhosa and E. moschata) (Norman \& Finn, 2014). Octopus vulgaris Cuvier, 1797 is a high-value species targeted by fisheries (Norman \& Finn, 2014) previously believed to be distributed throughout the subtropical/temperate east and west Atlantic, Indian and west Pacific Oceans (Roper et al., 1984). The planktonic larval life history of $O$. vulgaris has led to the hypothesis that a single, globally distributed species exists (Robson, 1929; Mangold, 1983). However, recent studies suggest populations previously treated as O. vulgaris may represent a complex of morphologically similar but genetically distinct vulgaris-like species, known as the 'O. vulgaris species complex' (Norman \& Hochberg, 2005; Vidal et al., 2010; Amor et al., 2014).

Corresponding author:

M.D. Amor

Email: mdamor@students.latrobe.edu.au
To date, several cryptic species have been discovered within the Octopus vulgaris group of octopuses (Söller et al., 2000; Leite et al., 2008; Amor et al., 2014). Octopus mimus Gould, 1852 was described from North Chile and its taxonomic distinctiveness was later supported by genetic data (Söller et al., 2000). The Atlantic Ocean is of particular taxonomic interest, as several members of the Octopus vulgaris species group have been reported from these waters (Voss \& Toll, 1998). Four of five proposed Octopus vulgaris 'Types' occur in the Atlantic Ocean along major continental coastlines (O. vulgaris sensu stricto; Mediterranean and Atlantic, Type I; Caribbean and Gulf of Mexico, Type II; South Brazil and Type III; South Africa) as well as in the shallow waters surrounding oceanic Islands (Norman et al., 2014). Furthermore, a new species, Octopus insularis Leite and Haimovici, 2008, was described from tropical North Brazil, where it is the predominant commercially targeted shallow-water species.

Two vulgaris-like taxa, Octopus occidentalis Steenstrup in Hoyle, 1886 and O. sanctaehelenae Robson, 1929, have previously been described from the shallow waters surrounding two tropical oceanic islands within the South Atlantic; Ascension and St Helena Islands respectively. Since the original descriptions of Octopus occidentalis and O. sanctaehelenae both species have been synonymized with O. vulgaris (Pickford, 1945, 1955), although more recently it has been suggested that they are valid species (Voss \& Toll, 1998; Norman \& 
Hochberg, 2005). To date, no DNA sequencing has been conducted on octopus species in the waters surrounding Ascension and St Helena Islands. Recent molecular studies have proven useful in identifying several morphologically similar species within the O. vulgaris species group (Söller et al., 2000; Leite et al., 2008; Amor et al., 2014), therefore, this study aims to use molecular data to determine the identity of octopus species present in the waters surrounding Ascension and St Helena Islands.

\section{METHDDS}

\section{Sampling}

Tissue samples from Ascension $(\mathrm{N}=3)$ and St Helena $(\mathrm{N}=1)$ were donated by researchers associated with South Atlantic Environmental Research Institute (SAERI), Falkland Islands. Octopus mimus samples $(\mathrm{N}=2)$ were donated by researchers associated with the University of Chile, Santiago. Tissue samples (arm or mantle tissue) were taken from individuals collected from Ascension Island (rocky outcrops at the southern limit of Georgetown in front of cemetery, $7^{\circ} 56.02 \mathrm{~S}$ $14^{\circ} 25^{\prime} 10 \mathrm{~W}$, low tide, wading depth) and St Helena (Lemon Valley, $15^{\circ} 56.4 \mathrm{~S} 5^{\circ} 44.52 \mathrm{~W}$, depth $13 \mathrm{~m}$; Figure 1). All tissue samples were stored at $-80^{\circ} \mathrm{C}$ in $\sim 90 \%$ ethanol until processing.

\section{Sequencing}

Genomic DNA was extracted from mantle or arm tissue $\left(\sim_{1-}\right.$ $2 \mathrm{~mm}^{2}$ ) using a QIAGEN DNeasy Blood and Tissue Kit according to the manufacturer's instructions. Partial COI sequences were amplified via PCR using the universal primers LCO and HCO (Folmer et al., 1994). $25 \mu \mathrm{L}$ reactions comprised $0.5 \mu \mathrm{L}$ forward primer $(10 \mu \mathrm{M}), 0.5 \mu \mathrm{L}$ reverse primer $(10 \mu \mathrm{M}), 12.5 \mu \mathrm{L}$ MyTaq Red Mix (Bioline), 9.5 $\mu \mathrm{L}$ $\mathrm{H}_{2} \mathrm{O}$ and $2 \mu \mathrm{L}$ DNA (5-10 ng total). PCR cycle conditions comprised a single initial denaturing step $\left(2 \mathrm{~min}\right.$ at $\left.95^{\circ} \mathrm{C}\right)$, 35 cycles of denaturing $\left(30 \mathrm{~s}\right.$ at $95^{\circ} \mathrm{C}$ ), annealing $(30 \mathrm{~s}$ at $48^{\circ} \mathrm{C}$ ) and extension ( $30 \mathrm{~s}$ at $72^{\circ} \mathrm{C}$ ) and a single final extension step $\left(5 \mathrm{~min}\right.$ at $72^{\circ} \mathrm{C}$ ). PCR products were sequenced by Macrogen Inc, Seoul, Korea. COI sequences generated in this study are accessible from GenBank under accession numbers KP056550-KP056555. Additional sequences from previously published work were obtained from GenBank (Table $\mathrm{S}_{1}$ ), including all available close relatives of the ingroup (Octopus bimaculoides, O. hummelincki, O.maya, O. mimus and O. salutii). Octopus cyanea was selected as the outgroup in order to root the tree (Acosta-Jofré et al., 2012). Multiple sequence alignments of the 482 base pair partial COI fragments were generated using the 'Muscle Alignment' feature (Larkin et al., 2007) in Geneious 7.1.3 (created by Biomatters; available from http://www.geneious.com/).

\section{Phylogenetic analyses}

jModelTest vo.1.1 (Posada, 2008) was used to carry out statistical selection of best-fit models of nucleotide substitution of the COI alignment. The appropriate model was selected based on 'goodness of fit' via the Akaike Information Criterion (AIC) (Akaike, 1974). Maximum likelihood (ML) topologies were constructed using PhyML v3.1 (Guindon et al., 2010).

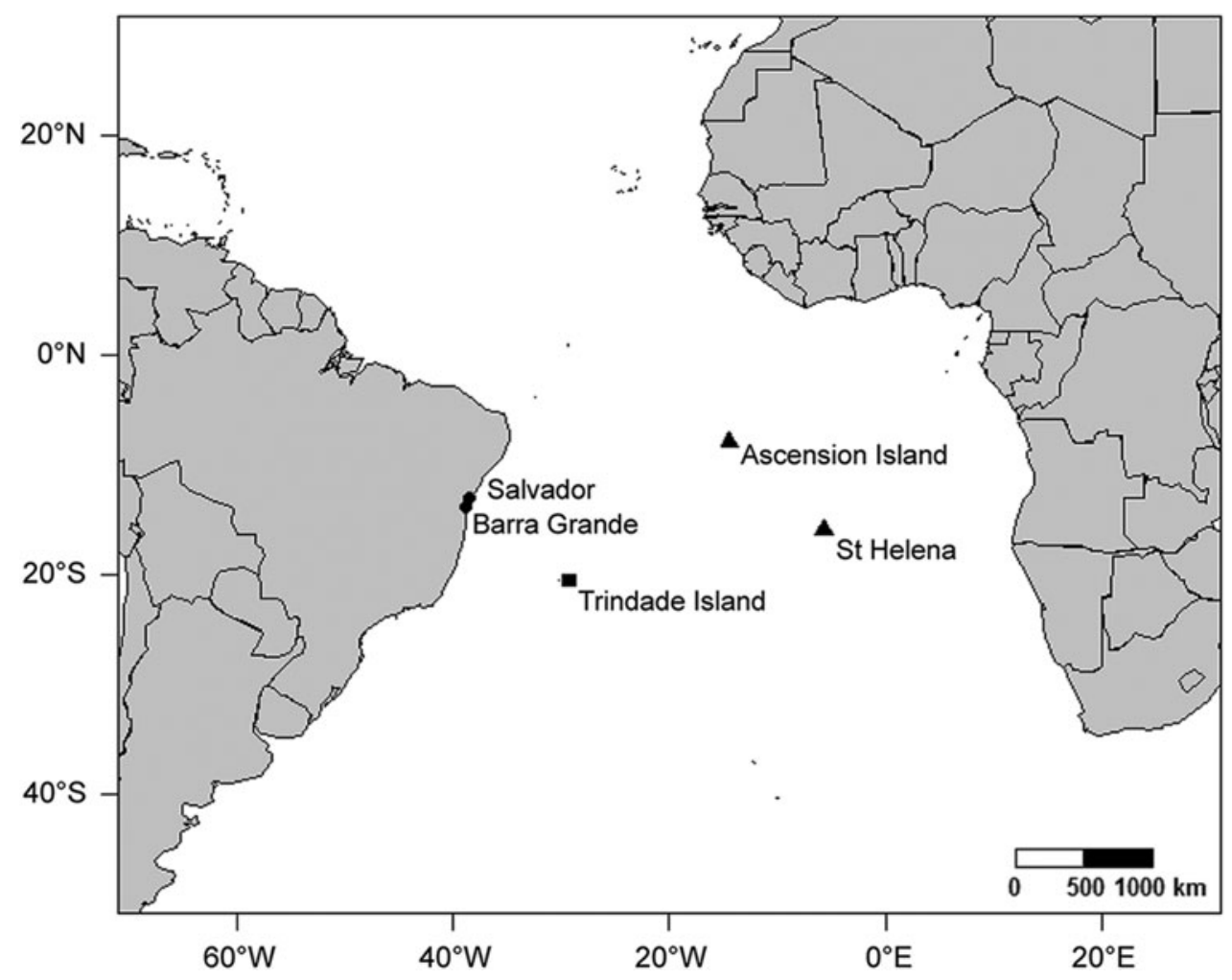

Fig. 1. Sampling locations of Octopus insularis from the South Atlantic Ocean (Ascension Island and St Helena). Locations sampled in the present study are represented by triangles. The square represents a locality (not sampled in the present study) from which Massy (1916) collected a specimen that she identified as $O$. occidentalis. Circles represent sampling locations of $O$. insularis from Brazil for which sequences were accessed from GenBank. 
Full heuristic searches were undertaken and model parameter values were treated as unknown and were estimated. Strength of support for internal nodes of ML construction was measured using 1000 bootstrap (BS) replicates. Bayesian inference (BI) marginal posterior probabilities (PP) were calculated using MrBayes v3.2 (Ronquist \& Huelsenbeck, 2003). Model parameter values were treated as unknown and were estimated. Random starting trees were used and the analysis was run for 5 million generations, sampling the Markov chain every 1000 generations. The program Tracer v1.3 (Rambaut \& Drummond, 2003) was used to ensure Markov chains had reached stationarity, and to determine the correct 'burn-in' for the analysis (the number of additional generations that must be discarded before stationarity is reached).

\section{Genetic distance}

Phylogenetic Analysis Using Parsimony (PAUP) v4.0 (Swofford, 2003) was used to calculate genetic distances using the model of best fit identified by jModelTest. Mean values of interspecific and intraspecific variations in number of mutations per site were calculated for COI.

\section{Timing of divergence}

Divergence times between the Octopus mimus and O. vulgaris groups were estimated based on an estimated rate of evolution for cephalopods; 3.81 substitutions per site per billion years (with 95\% highest posterior density around this mean of 2.43-5.24; Strugnell et al., 2012), within a generalized molecular clock.

\section{RESULTS}

\section{Phylogenetic analyses}

GTR + G was the preferred evolutionary model for the COI alignment and was utilized in $\mathrm{ML}$ and $\mathrm{BI}$ analyses and calculations of pairwise distances. Topologies resulting from $\mathrm{ML}$ and BI analyses recovered a highly supported clade containing individuals from Ascension, St Helena and Octopus insularis from north Brazil ( $\mathrm{BS}=81, \mathrm{PP}=1$; Figure 2). All individuals sampled from Ascension and St Helena shared a single haplotype (Haplotype 5a). This clade fell within a larger

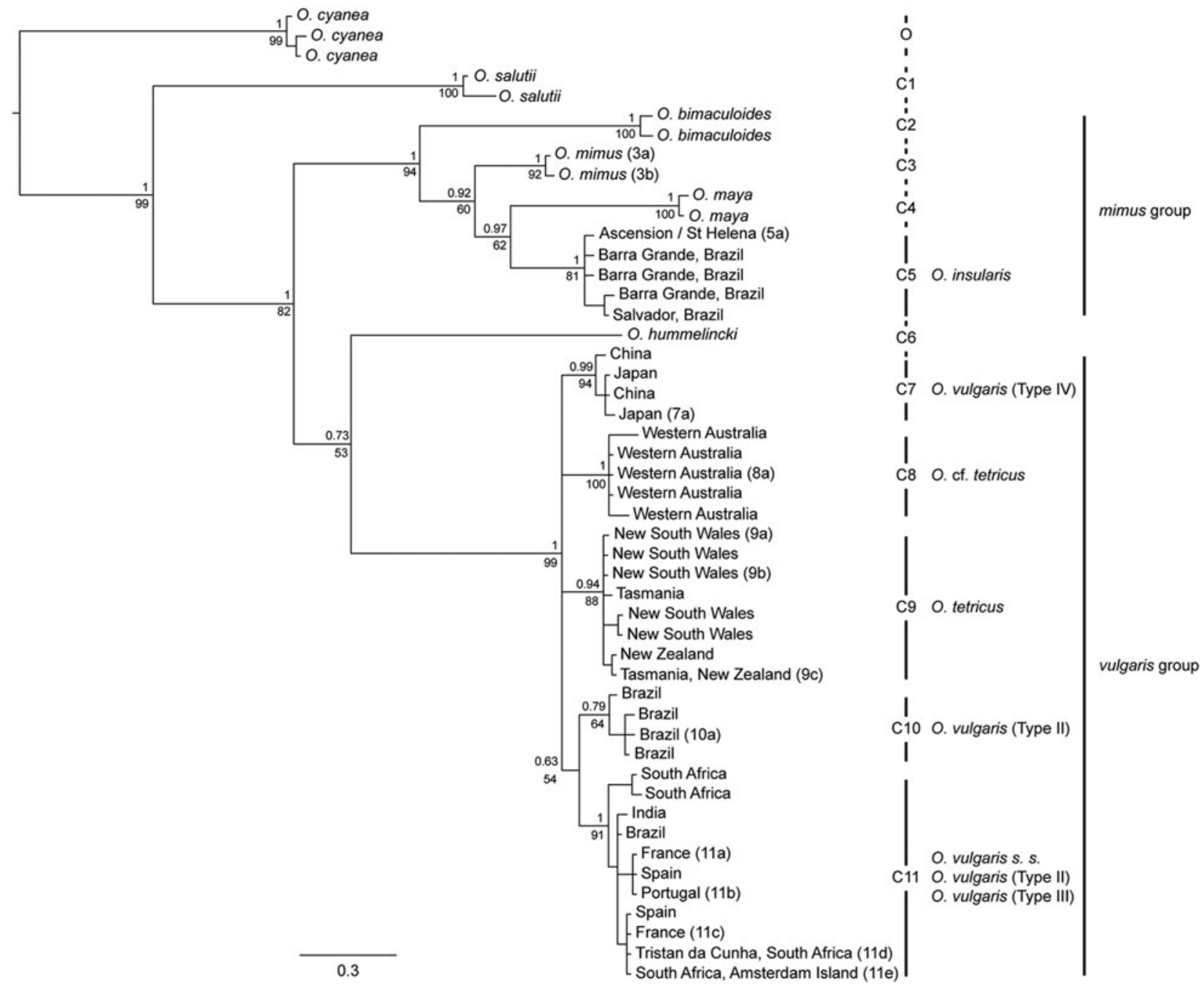

Fig. 2. Bayesian topology depicting the relationships among members of the Octopus vulgaris and O. mimus species groups. Analyses are based on partial sequences of the mitochondrial COI gene showing BI posterior probabilities above, and ML bootstrap values below major nodes. Outgroup (O) is composed of $O$. cyanea in order to root the tree. Node labels represent geographic locations represented and the haplotype character for a respective clade. Haplotype characters in parentheses and clade numbers $\left(\mathrm{C}_{1}-\mathrm{C}_{11}\right)$ correspond to those in Table $\mathrm{S}_{1}$. 
monophyletic clade (mimus group; $\mathrm{BS}=94, \mathrm{PP}=1$ ) which was also comprised of $\mathrm{O}$. bimaculoides $(\mathrm{BS}=100, \mathrm{PP}=1)$, O. maya $(\mathrm{BS}=100, \mathrm{PP}=1)$ and $O$. mimus $(\mathrm{BS}=92, \mathrm{PP}=$ 1). Members of the Octopus vulgaris species complex were placed in a highly supported monophyletic clade with O. tetricus and O. cf. tetricus from Australasia (vulgaris group; BS = 99, $\mathrm{PP}=1$ ). This clade comprised two known species identified in two highly supported distinct clades $(O$. tetricus (clade 9; $\mathrm{BS}=88, \mathrm{PP}=0.94$ ) and $O . \mathrm{cf}$. tetricus (clade 8; $\mathrm{BS}=100$, $\mathrm{PP}=1)$ ) and three suspected species that are currently treated under the name O. vulgaris (O. vulgaris s. $s$. (Clade 11; BS = 91, $\mathrm{PP}=1$ ), Brazilian O. vulgaris Type II (clade 10; $\mathrm{BS}=$ $64, \mathrm{PP}=0.79$ ) and Asian O. vulgaris Type IV (clade 7; $\mathrm{BS}=94, \mathrm{PP}=0.99)$ )

\section{Genetic distance}

Intraspecific distances within Octopus insularis individuals collected from north Brazil were identical to interspecific distances between $O$. insularis and individuals collected from Ascension and St Helena Islands (genetic distance $=0.007$; Table 1). Interspecific distances among O. tetricus, O. cf. tetricus and members of the O. vulgaris species complex ranged from 3-4.2\%, whilst intraspecific distance within each taxon ranged from $0.3-0.7 \%$. Interspecific distance among these taxa ranged from 5.1-12.1 times greater than each taxon's intraspecific distance. Genetic distance between the vulgaris and mimus groups (Figure 2) ranged from $14.7-26.0 \%$.

\section{Timing of divergence}

Based on GTR + G genetic distances, an approximate date of divergence of $\sim 19.0-40.9$ million years ago (ma) was estimated between the vulgaris and mimus groups.

\section{DISCUSSION}

This study used the mitochondrial 'barcode of life' gene, COI, to determine the identity of octopuses collected from waters surrounding Ascension and St Helena Islands. Three individuals from Ascension Island and a single individual from St Helena Island shared a single haplotype, suggesting these are conspecific taxa. Phylogenetic analyses placed these individuals into a highly supported monophyletic clade along with $O$. insularis individuals collected from north Brazil. The very low levels of genetic distance between individuals from Ascension/St Helena and O. insularis suggests the presence of gene flow among these populations and extends the known distribution of $O$. insularis to oceanic islands of the mid-Atlantic Ocean.

Octopus insularis has small eggs $<1.5 \mathrm{~mm}$ (Leite et al., 2008; de Lima et al., 2014) that hatch into planktonic paralarvae (Leite et al., 2008; Elias, 2012). While the pelagic larval duration of $O$. insularis is unknown, closely related $O$. vulgaris larvae have been shown to spend up to 60 days in the water column prior to settlement under laboratory conditions (Villanueva \& Norman, 2008). Ascension Island is situated within the seasonal activities of both the Central South Equatorial Current heading west, and the South Equatorial Counter Current heading east (Stramma, 1991; Stramma \& England, 1999). Equatorial current core velocities of $\sim 10-$ $20 \mathrm{~cm} \mathrm{~s}^{-1}$, and sometimes up to $60 \mathrm{~cm} \mathrm{~s}^{-1}$ (Stramma \&

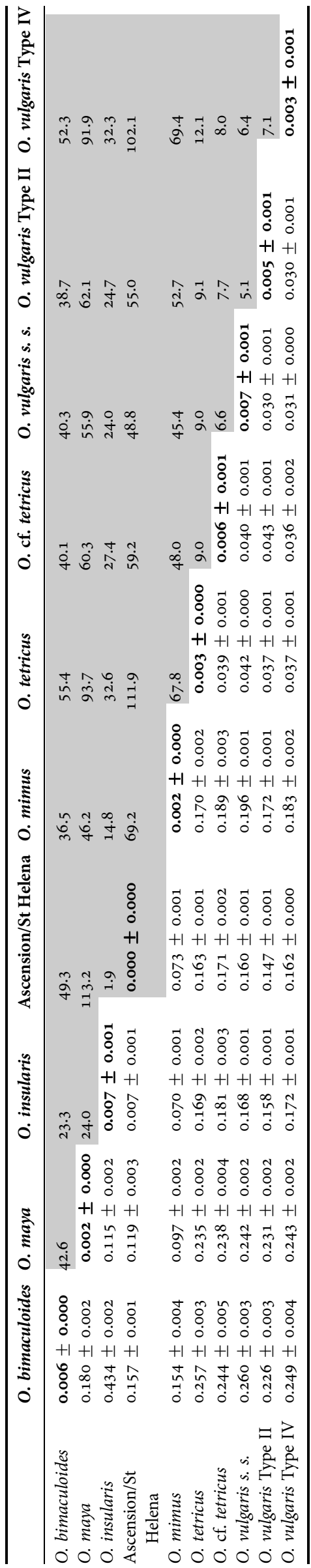


Schott, 1999), in this region could result in the unidirectional westward transport of at least $500-1000 \mathrm{~km}$ during the pelagic larval stage. This may be sufficient to maintain larval connectivity between Ascension Island/St Helena and mainland Brazil. For example, Amor et al. (2014) suggested O. tetricus was capable of maintaining gene flow between the east coast of the Australian mainland and New Zealand $(\sim 2000 \mathrm{~km})$, which is comparable to the distances between Brazil and Ascension/St Helena, which lie $\sim 2000-3000 \mathrm{~km}$ to the east of Brazil.

In the original description of Octopus insularis, Leite et al. (2008) briefly discussed the possibility of synonymy of $O$. insularis with two octopus species, O. occidentalis (Hoyle, 1886) and O. sanctaehelenae (Robson, 1929) previously described from Ascension and St. Helena, respectively. Both were described on the basis of single poorly preserved female type specimens. As molecular data are lacking for both nominal species, Leite et al. (2008) compared the morphology of $O$. insularis with the limited morphological data available for O. occidentalis and O. sanctaehelenae. Although differences were cited, the relatively low sample number and degraded state of historical type specimens makes comparisons difficult. The lack of molecular data for the type specimens of O. occidentalis and O. sanctaehelenae means it is impossible to determine whether they are conspecific with the specimens sequenced in this study. Consequently, the relationships among $O$. occidentalis, $O$. sanctaehelenae and $O$. insularis remain unresolved.

Also of note was that four species, Octopus bimaculoides, $O$. insularis, O. maya and O. mimus formed a highly supported monophyletic clade that was distinct from a clade containing all O. vulgaris Types, O. tetricus and O. cf. tetricus. Levels of interspecific distance within these clades ranged from $3-7 \%$, whilst interspecific distances between the two clades ranged from 14.7-26.0\%. Estimation of divergence times suggest the $O$. mimus group and $O$. vulgaris group arose from a common ancestor $\sim 19.0-40.9 \mathrm{ma}$. Due to the high levels of genetic divergence between these clades we propose distinct sub-groups within the previously single species group: (a) the vulgaris group (including $O$. vulgaris Types, O. tetricus and $O$. cf. tetricus and (b) the mimus group (including $O$. bimaculoides, O. insularis, O. maya and O. mimus); Figure 1.

Clade 11 in Figure 2, contains samples of Octopus vulgaris sensu stricto and individuals from South Africa (vulgaris Type III; Norman et al., 2014), Tristan da Cunha, India, Amsterdam Island and one individual from Brazil (vulgaris Type II; Norman et al., 2014). The remaining vulgaris Type II samples from Brazil $(\mathrm{N}=15)$ fell out into their own clade (clade 6), suggesting that the Brazilian species currently being treated under the name vulgaris may be polyphyletic. With O. insularis this potentially brings the total of vulgarislike taxa in Brazil to three. However, specimen 'OvuPA 173' (GenBank accession no. KF844027) was obtained from the stomach contents of a red snapper caught off North Brazil (Sales et al., 2013), therefore the exact origin (location and depth) of this specimen remains unknown.

\section{Conclusions and future work}

This study confirms the presence of Octopus insularis in the tropical mid-Atlantic Ocean surrounding the islands of Ascension and St Helena, between 2000 and $3000 \mathrm{~km}$ from the Brazilian mainland. Two historical species names, $O$. occidentalis and $O$. sanctaehelenae, were described from these islands, however their limited and poorly preserved type material and the absence of molecular support means their taxonomic status and relation to $O$. insularis remain unresolved. Octopus insularis is the primary shallow-water octopod targeted by fisheries in north Brazil. The present contribution to a better understanding of its distribution will aid in the sound management of this and other species in the $O$. vulgaris and $O$. mimus species groups, which together form a valuable cosmopolitan resource.

\section{SUPPLEMENTARY MATERIAL}

To view supplementary material for this article, please visit http://dx.doi.org/10.1017/So025315415000958

\section{ACKNDWLEDGEMENTS}

We thank Dr Judith Brown (Ascension Island Government) and Prof Peter Wirtz (Centre for Marine Sciences, University of Algarve, Portugal) for donating octopus tissue samples. We thank Maria Cecilia Pardo Gandarillas (Department of Ecological Sciences, Sciences Faculty, University of Chile) for donating tissue samples of Octopus mimus. We are grateful to the Shallow Marine Surveys Group and the South Atlantic Environmental Research Institute for organizing the expedition. We are also very grateful to Ascension Island Government, the members of staff at the Conservation Centre and Ascension Island Dive Club for their cooperation, accommodation and hospitality. We are grateful to British Forces South Atlantic Islands for their logistic support. The comments from two anonymous reviewers helped improve this manuscript.

\section{FINANCIAL SUPPDRT}

The funding for field work and sample collection came from a grant to the Shallow Marine Surveys Group from the Darwin Initiative (EIDCFo12). A La Trobe University Faculty of Science, Technology and Engineering grant awarded to JMS also supported this study.

\section{REFERENCES}

Acosta-Jofré M.S., Sahade R., Laudien J. and Chiappero M.B. (2012) A contribution to the understanding of phylogenetic relationships among species of the genus Octopus (Octopodidae: Cephalopoda). Scientia Marina 76, 311-318.

Akaike H. (1974) A new look at the statistical model identification. IEEE Transactions on Automatic Control 19, 716-723.

Amor M.D., Norman M.D., Cameron H.E. and Strugnell J.M. (2014) Allopatric speciation within a cryptic species complex of Australasian octopuses. PLoS ONE 9, e98982. doi: 98910.91371/ journal.pone.0098982.

de Lima F.D., Leite T.S., Haimovici M. and Oliveira J.E.L. (2014) Gonadal development and reproductive strategies of the tropical octopus (Octopus insularis) in northeast Brazil. Hydrobiologia 725 , 7-21. 
Elias N.H. (2012) Primeira Descricao das Paralarvas de Octopus insulari (Leite \& Haimovici, 2008). A Partir de Reprodutores Mantidos em Laboratorio.

FAO (2012) Fisheries and acquaculture statistics 2010. FAO yearbook. Rome: Food and Agriculture Organization of the United Nations.

Folmer O., Black M., Hoeh W., Lutz R. and Vrijenhoek R. (1994) DNA primers for amplification of mitochondrial Cytochrome C Oxidase subunit from diverse metazoan invertebrates. Molecular Marine Biology and Biotechnology 3, 294-299.

Guindon S., Dufayard J.F., Lefort V., Anisimova M., Hordijk W. and Gascuel O. (2010) New algorithms and methods to estimate Maximum-Likelihood phylogenies: assessing the performance of PhyML 3.o. Systematic Biology 59, 307-321.

Hoyle W.E. (1886) Report on the cephalopods collected by H.M.S Challenger during the years 1873-76. In Thompson C.W. and Murray J. (eds) The voyage of H.M.S. Challanger, zoology, Volume 16. London: Her Majesty's Stationery Office, pp. 1-245.

Larkin M.A., Blackshields G., Brown N.P., Chenna R., McGettigan P.A., McWilliam H., Valentin F., Wallace I.M., Wilm A., Lopez R., Thompson J.D., Gibson T.J. and Higgins D.G. (2007) Clustal W and Clustal X Version 2.o. Bioinformatics 23, 2947-2948.

Leite T.S., Haimovici M., Molina W. and Warnke K. (2008) Morphological and genetic description of Octopus insularis, a new cryptic species in the Octopus vulgaris complex (Cephalopoda : Octopodidae) from the tropical South-Western Atlantic. Journal of Molluscan Studies 74, 63-74.

Mangold K. (1983) Octopus vulgaris. In Boyle P.R. (ed.) Cephalopod life cycles, Volume 1. London: Academic Press, pp. 335-364.

Massy A.L. (1916) British Antarctic (“Terra Nova”) Expedition, 1910 Zoology 2, 141-175.

Norman M.D. and Finn J.K. (2014) World octopod fisheries. In Jereb P., Roper C.F.E., Norman M.D. and Finn J.K. (eds) Cephalopods of the world. An annotated and illustrated catalogue of cephalopod species known to Date. Octopods and vampire squids, Volume 3. Rome: Food and Agriculture Organization of the United Nations, pp. 9-21.

Norman M.D., Finn J.K. and Hochberg F.G. (2014) Family octopodidae. In Jereb P., Roper C.F.E., Norman M.D. and Finn J.K. (eds) Cephalopods of the world. An annotated and illustrated catalogue of cephalopod species known to date. Octopods and vampire squids. FAO species catalogue for fishery purposes. No. 4. Volume 3. Rome: Food and Agriculture Organization of the United Nations, pp $36-215$.

Norman M.D. and Hochberg F.G. (2005) The current state of octopus taxonomy. In Proceedings of the International Workshop and Symposium of Cephalopod International Advisory Council, Phuket, 2003. Phuket Marine Biological Center Special Publication, Volume 66, pp. $127-154$.

Pickford G.C. (1945) Le Poulpe Americain: a study of the littoral Octopoda of the Western Atlantic. Transactions of the Connecticut Academy of Arts and Sciences 36, 701-811.

Pickford G.C. (1955) A revision of the Octopodinae in the collections of the British Museum. Bulletin of the British Museum (Natural History). Zoology 3, 151-167.

Posada D. (2008) jModelTest: phylogenetic model averaging. Molecular Biology and Evolution 25, 1253-1256.
Rambaut A. and Drummond A.J. (2003) Tracer 1.3. Oxford University. http://tree.bio.ed.ac.uk/software/tracer

Robson G.C. (1929) A monograph of the recent cephalopoda, Part I Octopodinae, Volume 1. London: British Museum (Natural History).

Ronquist F. and Huelsenbeck J.P. (2003) MrBayes 3: Bayesian phylogenetic inference under mixed models. Bioinformatics 19, 1572-1574.

Roper C.F.E., Sweeney M.J. and Nauen C.E. (1984) FAO species catalogue. Cephalopods of the world: an annotated and illustrated catalogue of species of interest to fisheries. Volume 3 (125). FAO Fisheries Synopsis, pp. $1-277$.

Sales J.B.D.L., Rego P.S.D., Hilsdorf A.W.S., Moreira A.A., Haimovici M., Tomás A.R., Batista B.B., Marinho R.A., Markaida U., Schneider H. and Sampaio I. (2013) Phylogeographical features of Octopus vulgaris and Octopus insularis in the south-eastern Atlantic based on the analysis of mitochondrial markers. Journal of Shellfish Research 32, 325-339.

Söller R., Warnke K., Saint-Paul U. and Blohm D. (2000) Sequence divergence of mitochondrial DNA indicates cryptic biodiversity in Octopus vulgaris and supports the taxonomic distinctiveness of Octopus mimus (Cephalopoda : Octopodidae). Marine Biology 136, $29-35$.

Stramma L. (1991) Geostrophic transport of the South Equatorial Current in the Atlantic. Journal of Marine Research 49, 281-294.

Stramma L. and England M. (1999) On the water masses and mean circulation of the South Atlantic Ocean. Journal of Geophysical Research $104,863-883$

Stramma L. and Schott F. (1999) The mean flow field of the tropical Atlantic Ocean. Deep-Sea Research II 46, 279-303.

Strugnell J.M., Watts P.C., Smith P.J. and Allcock A.L. (2012) Persistent genetic signatures of historic climatic events in an Antarctic octopus. Molecular Ecology 21, 2775-2787.

Swofford D.L. (2003) PAUP*. Phylogenetic analysis using parsimony (*and other methods). Version 4. Sunderland, MA: Sinauer Associates.

Vidal É.A.G., Fuentes L. and da Silva L.B. (2010) Defining Octopus vulgaris populations: a comparative study of the morphology and chromatophore pattern of paralarvae from northeastern and southwestern Atlantic. Fisheries Research 106, 199-208.

Villanueva R. and Norman M.D. (2008) Biology of the planktonic stages of benthic octopuses. In Gibson R.N., Atkinson R.J.A. and Gordon J.D.M. (eds) Oceanography and marine biology: an annual review. Boca Raton, FL: CRC Press, pp. 105-202.

and

Voss G. and Toll R. (1998) The systematics and nomenclatural status of the Octopodinae described from the Western Atlantic Ocean. In Voss N., Vecchione M., Toll R. and Sweeney M. (eds) Systematics and biogeography of cephalopods. Volume II. Washington, DC: Smithsonian Contributions to Zoology, pp. 457-454.

\section{Correspondence should be addressed to:}

M. Amor

Department of Ecology, Environment and Evolution, La Trobe University, Kingsbury Dr, Melbourne, Victoria 3086, Australia email: mdamor@students.latrobe.edu.au 